Отже, в дослідженні констатовано факт необхідності поширення економічних знань та підготовки молоді до умов ринкової системи господарювання, обгрунтовано доцільність підготовки кадрів - менеджерів, маркетологів, підприємців, банкірів, висококваліфікованих фахівців виробничої сфери. Доведено, що теоретична економічна підготовка учнів здійснюється з урахуванням того, що вітчизняна, економічна освіта швидко не конституюється на постулатах і концепціях марксистсько-ленінської теорії і зорієнтувалася на передові вчення і теорії країн з розвинутою ринковою економікою.

\title{
Література
}

1. Аксьонова О. В. Методика викладання економічних дисциплін : [навч. посіб.] / О. В. Аксьонова. - К. : КНЕУ, 2006. 708 с. 2. Вачевський М. В. Основи економіки: [навч. посіб. для учнів ліцеїв, коледжів, гімназій та загальноосвітніх шкіл 10-11-12 кл.] / М. Вачевський, В. Мадзігон. - К. : Педагогічна думка. 2007. - 612 с. 3. Енциклопедія освіти / В. Г. Кремінь (гол. ред.). К. : Юрінком Інтер, $2008 . \quad-1040$ с. 4. Нисимчук А. С. Экономическое образование школьников: [кн. для учителя] / А. С. Нисимчук. - М.: Просвещение, $1991 .-128$ с. 5. Падалка О. С. Економічне виховання в школі / О. С. Падалка // Трудова підготовка в закладах освіти. - 1998. - №4. - С. 29-32. 6. Петрощук Н. Профільне навчання в школах Києва / Н. Петрощук // Директор школи. - 2011. - №18. - С. 8-11. 7. Прокопенко И. Ф. Экономическое образование школьников: [учеб. пособ. для учит. сред. шк.] / И. Ф. Прокопенко, Е. Н. Камышанченко, В. И. Лозовая. - Х. : Основа, 1995. - 172 с. 8. Шпак О. Т. Економічна підготовка педагогічних кадрів в системі безперервної освіти / НПУ ім. Драгоманова. - К. : Четверта хвиля, 2000. - 352 с.

Ю. В. Курбатова, кандидат пед. наук, ст. викладач, Дніпропетровський державний аграрний університет

\section{ПРИНЦИПИ РОЗВИТКУ ПРОФЕСІЙНОГО СТАНОВЛЕННЯ МАЙБУТНЬОГО АГРОНОМА}

У статті наведено модель розвитку професійного становлення майбутнього агронома в навчально-виховному прочесі аграрного університету та докладно розглянуто принципи, щьо сприяють розвитку професійного становлення майбутнього агронома

Ключові слова: професійне становлення, розвиток професійного становлення, педагогічні принципи, педагогічні умови. 
В статье представлена модель развития профессионального становления будущего агронома в учебно-воспитательном прочессе аграрного университета и подробно рассмотрены принципь, способствующие развитию профессионального становления будущего агронома.

Ключевые слова: профессиональное становление, развитие профессионального становления, педагогические приниипь, педагогические условия.

The model of professional development of the future agronomist in the teaching and educational process of agrarian university and detailed principles of future agronomist professional development are considered in this article.

Key words: professional formation, development of professional formation, pedagogical principles, pedagogical conditions.

У світлі економічних, соціальних змін, що відбуваються в сучасній Україні, зважаючи на умови ринку праці, що постійно змінюються, на зростаючі вимоги до сучасних фахівців, а особливо до випускників вищих навчальних закладів освіти постає питання розвитку професійного становлення майбутніх фахівців на етапі підготовки в університеті. Україна нині потребує висококваліфікованих агрономів, які можуть приймати зважені та, водночас, сміливі рішення стосовно систем та засобів землеробства, можливостей отримання високих врожаїв та питань рекультивації промислових територій. Проте вимоги до підготовки саме цих фахівців особливо не змінювалися протягом років незалежності Україні і мета фахової підготовки спрямована саме на надання студентам фахових знань, які є лише часткою професійного становлення i випускники агрономічних факультетів інколи губляться на сучасному ринку праці.

Під час розроблення моделі розвитку професійного становлення майбутнього агронома в навчально-виховному процесі аграрного університету та вивчення принципів, що сприяють досягненню результату, ми спиралися на дослідження науковців, які розглядали питання педагогічного моделювання, i також розвиток професійного становлення майбутнього фахівця - як процес кардинальної перебудови особистості, який передбачає перетворення їі внутрішнього світу, а саме О. Пєхоти, В. Безрукова, Г. Селевка, А. Маркової, Л. Мітіної, А. Бодальова, А. Деркача, Н. Кузьміної, А. Реан та ін.

Mema cmammi - розглянути й обгрунтувати загальнопедагогічні і специфічні принципи, що сприяють розвитку професійного становлення майбутнього агронома в навчально-виховному процесі аграрного університету. 
Моделювання, на думку науковців [2, с. 322], є одним із ефективних методів пізнання й перетворення світу, який використовується як універсальна форма пізнання у будь-якій сфері людської діяльності. Модель заміщує собою об'єкт, що досліджується, а іï вивчення як системи дає змогу отримати інформацію про іншу систему. Спираючись на думку О. Пєхоти про те, що модель - це інструмент для регулювання процесу особистісного професійного розвитку фахівця [3, с. 80], вважаємо за можливе використання цього інструмента в нашому дослідженні.

Під час створення моделі процесу розвитку професійного становлення майбутнього агронома в навчально-виховному процесі аграрного університету спираємось на думку про те, що педагогічне конструювання досягає найвищої ефективності лише тоді, коли воно базується на певній сукупності науково обгрунтованих та взаємопов'язаних принципів, зокрема таких: а) принцип дотримання послідовності переходів від теоретичної моделі до нормативної, а від останньої - до конкретних програм діяльності; б) принцип відповідності засобів, що пропонуються на кожному етапі конструювання, педагогічним цілям та умовам здійснення процесу, який досліджується.

Під час моделювання процесу професійного становлення майбутнього агронома було використано ідеї, наведені у працях науковців О. Пєхоти [3], Г. Селевка [4] та ін. Відповідно до наведених вище міркувань створена нами модель процесу розвитку професійного становлення майбутнього агронома містить такі компоненти: мету, організаційно-педагогічні умови, діагностування, етапи та очікуваний результат процесу (рис. 1).

Для побудови моделі процесу розвитку професійного становлення майбутнього агронома звертаємось до тези Ю. Бабанського про визначальну роль мети щодо інших складників педагогічної діяльності [1, с. 8]. За мету ставимо сформованість готовності майбутнього агронома до професійної діяльності. В основу запропонованої нами моделі процесу розвитку професійного становлення майбутнього агронома було покладено такі організаційнопедагогічні умови: здійснення науково-методичної підготовки викладачів аграрного університету до управління процесом розвитку професійного становлення майбутнього 
агронома; діалогізація професійної підготовки студентів 3 використанням сукупності відповідних методів і прийомів навчання, що сприяє підвищенню рівня засвоєння професійних знань, умінь і навичок, розвитку ключових i фахових компетенцій; забезпечення спрямованості навчально-виховного процесу агрономічного факультету аграрного університету на розвиток інтересу студентів до майбутньої професійної діяльності; активізація пізнавальної діяльності студентів шляхом імітації на заняттях ситуацій, пов'язаних з професійною діяльністю.

Для досягнення визначеної мети та виконання поставлених завдань у розроблену модель процесу розвитку професійного становлення майбутнього агронома закладено такі педагогічні принципи:

Загальнодидактичні:

1. Принции системності. Він робить можливим обгрунтування та розробку мети, принципів, методів і засобів процесу розвитку професійного становлення студентів-агрономів в аграрному університеті, визначення організаційнопедагогічних умов і факторів впливу на розвиток професійного становлення майбутнього агронома. Під час застосування принципу системності встановлюється причиннонаслідковий характер досліджуваних процесів і явищ, ієрархічність структури системи, яка вивчається. Отже, цей принцип надає змогу забезпечити цілісність процесу розвитку професійного становлення майбутнього агронома і взаємодію його структурних компонентів, здійснювати цілеспрямований вплив на його хід, прогнозувати результати експериментальної роботи.

Принцип системності визначає цільову спрямованість усіх компонентів процесу розвитку професійного становлення на вирішення завдань формування й розвитку системи світоглядних і ціннісних уявлень; професійних знань, умінь і навичок; професійно значущих особистісних якостей.

2. Принцип наступності та безперервності. Він передбачає, що розвиток професійного становлення майбутнього агронома у навчально-виховному процесі аграрного університету $є$ одним із етапів, які становлять цілісну систему процесу професійного розвитку особистості. Він $є$ безперервним і триває протягом усього періоду професійної підготовки і діяльності фахівця. Безперервність розуміємо як процес особистого, соціального й професійного розвитку особистості. При 
цьому спираємось на концепцію навчання впродовж усього життя, яка передбачає постійну необхідність і можливість набуття фахівцями нових знань на всіх етапах професійної діяльності для підтримання своєї професійної компетентності на конкурентоспроможному рівні.

3. Принциип науковості. Згідно 3 ним, навчання здійснюється на основві перевірених наукових фактів, відображення новітніх досягнень науки. Реалізація принципу науковості передбачає впровадження у навчальний процес найновіших досягнень педагогіки, психології, методики; розкриття логіки дисципліни, яка вивчається, що забезпечує надійне підгрунтя для засвоєння нових наукових понять; систематичне інформування студентів про нові досягнення в науці і техніці; розгляд спірних наукових проблем. У такий спосіб відбувається зв'язок теорії з практикою, орієнтація студентів на застосування теоретичних знань для виконання практичних завдань.

4. Приниип систематичності й послідовності, тобто послідовний виклад навчального матеріалу, виокремлення основного, логічний перехід від засвоєного матеріалу до нового. Спочатку потрібно вивчати той навчальний матеріал, з яким буде здійснюватися порівняння наступного, тобто нового, i лише потім починати вивчення останнього. За відсутності систематичності виникають великі прогалини у логічній структурі знань. Що стосується послідовності, то потрібно йти від простіших зв'язків до складніших. Поповнення знань - це нарощування зв'язків, їхні поглиблення і розширення. Велике значення має систематичність і послідовність у вихованні поглядів, переконань, культури спілкування та поведінки, позитивних особистісних якостей. Принцип систематичності і послідовності є певним доповненням до принципу науковості й доступності.

Специфічні:

1. Принции активності. Передбачає активну позицію майбутнього агронома в пізнавальній діяльності. Розвиток професійного становлення майбутнього агронома відбувається під впливом багатьох чинників. Водночас слід урахувати, що і сам майбутній агроном $\epsilon$ не пасивним об'єктом навчання, а суб' єктом свого власного формування та розвитку. Тому одним із результатів особистісних змін студентів у процесі розвитку професійного становлення $\epsilon$ сформованість професійної активності особистості. Це передбачає здатність майбутнього агронома до самостійного засвоєння професійного 
досвіду, активного використання його у власній професійній діяльності, дедалі більшої автономності при виконанні професійних обов'язків і прийняття рішень у нестандартних ситуаціях.

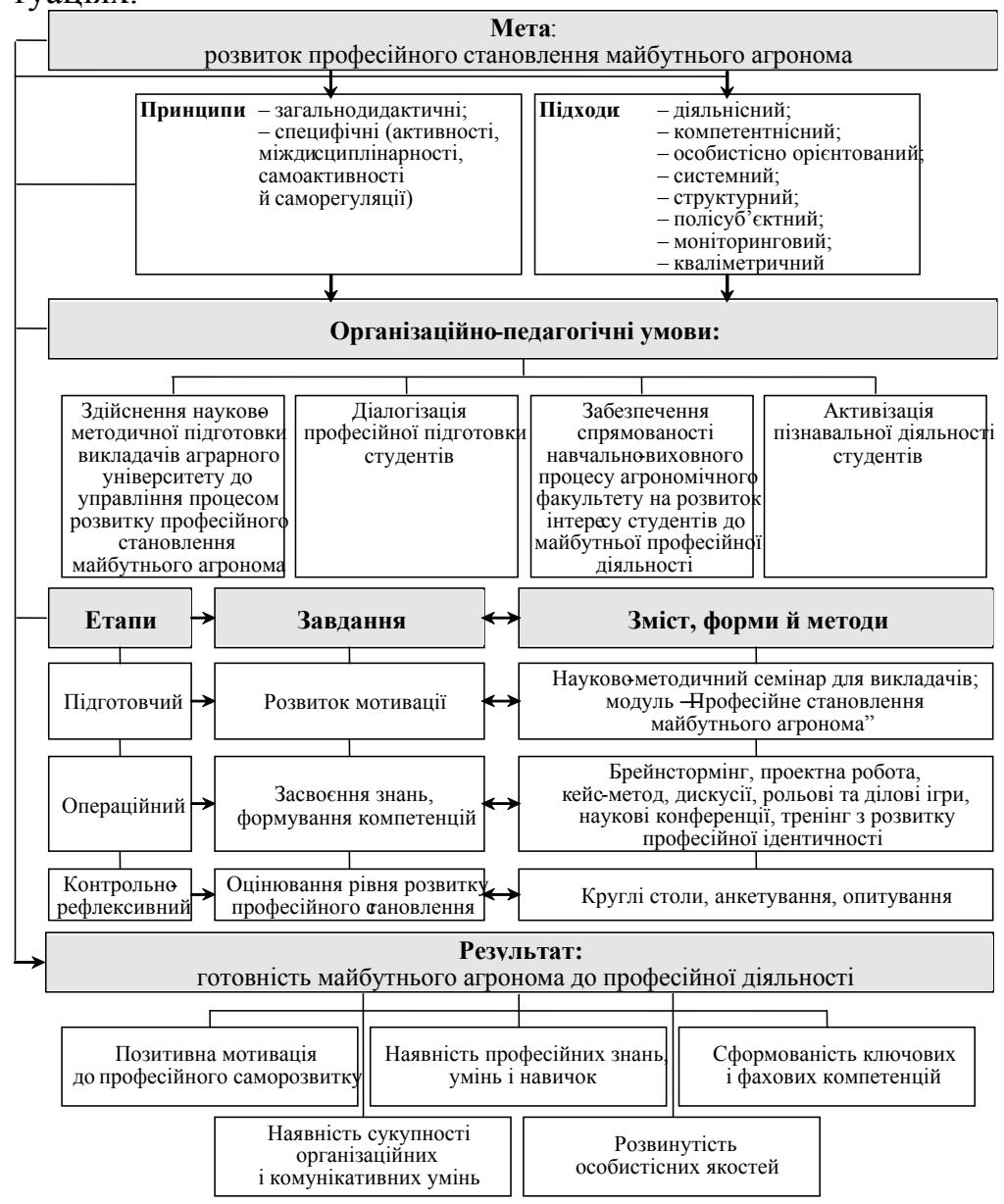

Рис. 1. Модель процесу розвитку професійного становлення майбутнього агронома

2. Принциип міждисциилінарності. Він вимагає підвищення рівня узагальнення і логічності знань, які у вигляді окремих 
елементів студенти засвоюють під час вивчення певних дисциплін.

У зв'язку з необхідністю невпинного вдосконалення підготовки майбутніх агрономів до життя у сільському соціумі як ключової постаті на селі, «господаря землі» доцільним $\epsilon$ використання потенціалу міждисциплінарних зв'язків, які дають змогу розвивати у майбутнього агронома адекватне ставлення до своєї професії й формувати особистісні якості.

Проте до цього часу у підготовці фахівців-агрономів переважають тенденції до вузькопрофільних знань, орієнтація студентів на розв'язання стандартних професійних завдань шаблонними засобами. Вузькодисциплінарна орієнтація навчально-виховного процесу в аграрному університеті спричинює неприйняття майбутніми агрономами навчальних цінностей, відсутність бажання навчатися й оволодівати професією, відокремлення життєвих цінностей від навчальнопізнавальних. Знання студентів мають дискретний характер, у них не складається єдина картина теорії і практики, відсутнє уміння застосовувати знання на практиці, а тим паче виділяти ключові проблеми, які потребують розв'язання. Отже, при традиційному навчанні у студентів залишаються лише розрізнені відомості, деякі факти, але не складається система знань, необхідних для успішного виконання професійних функцій.

У процесі реалізації міжпредметних зв'язків у майбутніх агрономів розширюється світогляд, розвивається логічне мислення, активізується увага, зростає інтерес до вивчення дисциплін навчального плану, розкриваються природно-наукові основи дій і операцій майбутньої професійної діяльності, стають більш дієвими набуті студентами знання. При реалізації принципу міждисциплінарності відбувається інтеграція навчальних дисциплін на основі єдності всіх завдань і перехід від вузькопредметних форм навчання до взаємопов'язаного широкого комплексу засвоєння знань, умінь i навичок.

3. Принции самоактивності й саморегулящії сприяє розвитку у студентів-агрономів бажання до професійного саморозвитку і самовдосконалення, формує здатність до прийняття самостійних рішень у професійній діяльності й почуття відповідальності за їх реалізацію. Порівняно з поняттям «активність» у феномені «самоактивність» акцентується внутрішня зумовленість, вмотивованість певних дій, поведінки індивіда, 
хоч і не принижується роль зовнішніх чинників. Через самоактивність майбутній агроном здатний реалізувати свій особистісний потенціал у процесі розвитку професійного становлення. Принцип саморегуляції пов'язаний із плануванням майбутнім фахівцем цілеспрямованих, «програмованих», змін у собі. Саморегуляція передбачає усвідомлення своїх внутрішніх резервів й оволодіння ними, зокрема, для власного професійного розвитку.

При розробленні моделі професійного становлення майбутнього агронома у навчально-виховному процесі аграрного університету спиралися на компетентнісний, діяльнісний i особистісно орієнтований підходи. Крім того, вважаємо за необхідне звернутися також до таких підходів до організації педагогічного впливу на професійне становлення майбутнього агронома, як системний, структурний, полісуб'єктний, моніторинговий, кваліметричний.

Системний підхід означає в контексті нашого дослідження поетапний, логічно послідовний процес організації професійного становлення майбутнього агронома, починаючи з визначення необхідних знань, умінь і навичок, проведення експерименту для формування мотивації щодо їх отримання та оволодіння професією, розробки сукупності відповідних засобів і завершуючи оцінюванням ефективності проведення навчання. Структурний підхід надає змогу аналізувати елементи системи та їх взаємозв'язки, з'ясувати внутрішні залежності між елементами системи, отримати уявлення про внутрішню організацію досліджуваної системи. Полісуб'єктний підхід базується на вірі в позитивний потенціал людини, в іiі безмежні творчі можливості постійного розвитку й самовдосконалення. Згідно з положеннями полісуб'єктного підходу, розвиток фахівця відбувається тільки в умовах відносин 3 іншими людьми, побудованих за принципами діалогу, і в процесі власної пізнавальної і професійної діяльності. При застосуванні кваліметричного підходу забезпечується кількісне оцінювання якості процесу професійного становлення майбутнього агронома. Оцінювання реалізується шляхом контролю (вимірювання конкретних характеристик). До моніторингового підходу, який передбачає стеження за якимнебудь процесом, звертаємося 3 метою виявлення відповідності процесу професійного становлення майбутнього агронома бажаному результату. 
Отже, результатом розвитку професійного становлення майбутнього агронома в навчально-виховному процесі аграрного університету є його готовність до професійної діяльності, яка включає: позитивну мотивацію до професійного саморозвитку; наявність професійних знань, умінь і навичок; сформованість ключових і фахових компетенцій; наявність сукупності комунікативних і організаційних умінь; розвинутість професійно важливих особистісних якостей.

\section{Література}

1. Бабанский Ю. К. Интенсификация процесса обучения / Ю. К. Бабанский. - М. : Знание, 1987. - 80 с. 2. Педагогика: большая современная энциклопедия / [сост. Рапацевич Е. С.]. - Мн. : Современное слово, 2005. - 720 с. 3. Пехота Е. Н. Индивидуализация профессионально-педагогической подготовки учителя : [монография] / Е. Н. Пехота ; под общ. ред. И. А. Зязюна. - К. : Вища школа, 1997. - 176 с. 4. Селевко Г. К. Образовательные технологии : [учеб. пособ.] / Г. К. Селевко. - М. : Народное образование, 1998. $-256 \mathrm{c}$.

I. Г. Максименко, кандидат пед. наук, доцент, ДВНЗ «Криворізький наиіональний університет»

\section{ДІАЛОГОВЕ НАВЧАННЯ ЯК УМОВА ГУМАНІЗАЦЇ̈ ПЕДАГОГІЧНОЇ ДІЯЛЬНОСТІ}

У статті розглянуто організаџію діалогового навчання як умови гуманізації педагогічної діяльності.

Ключові слова: діалог, діалогове навчання, педагогічна діяльність, гуманізациія.

В статье рассмотрена организачия диалогового обучения как условия гуманизации педагогической деятельности.

Ключевые слова: диалог, диалоговое обучение, педагогическая деятельность, гуманизачия.

The article deals with the organization of dialogue training as a condition of humanization of educational activities.

Key words: dialogue, dialogue training, educational activities, humanism.

Становлення демократичного суспільства, входження України в європейський освітній простір висуває вимоги до вищої школи, що потребує їі модернізація. Оновлення системи освіти здійснюється на різних рівня і відбувається за ра- 